International Journal of Instruction e-ISSN: 1308-1470 • www.e-iji.net
July $2019 \bullet$ Vol.12, No.3
p-ISSN: $1694-609 X$
pp. 405-424

Received: $12 / 11 / 2018$

Revision: 05/04/2019

Accepted: 12/04/2019

OnlineFirst:09/05/2019

\title{
The Relationship between using Information and Communication Technology in Education and the Mathematics Achievement of Students
}

\section{Petronella Elize Saal}

Department of Science, Mathematics and Technology Education, University of Pretoria, Faculty of Education, Groenkloof, Pretoria, South Africa, saal.pet@gmail.com

\section{Linda van Ryneveld}

Department of Science, Mathematics and Technology Education, University of Pretoria, Faculty of Education, Groenkloof, Pretoria, South Africa, linda.vanryneveld@up.ac.za

\section{Marien Alet Graham}

Department of Science, Mathematics and Technology Education, University of Pretoria, Faculty of Education, Groenkloof, Pretoria, South Africa, marien.graham@up.ac.za

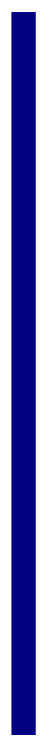

In his State of the Nation address on 7 February 2019, the president of the Republic of South Africa. Mr. Cyril Ramaphosa, stated that the government would provide digital workbooks and textbooks to every school child in South Africa by 2025. (De Villiers, 2019). This announcement begs the question how effective the incorporation of Information and Computer Technology (ICT) is in Education.

This study adapted the comprehensive model of educational effectiveness created by Creemers (1994) to explore the relationship between the use of educational technology in mathematics and mathematics achievement in South Africa. The questionnaire responses from Grade 5 students, their mathematics teachers and school principals, participating in TIMSS 2015 research project, have been utilised in this study. Findings from descriptive statistics showed that almost $90 \%$ of the students were taught by teachers who did not have computers in their mathematics classrooms. Consequently, only $10 \%$ of students were taught by teachers who utilised computers in the classroom. The minority of these teachers used computers 'every, or almost every, day' in order to explore mathematical concepts $(8.37 \%)$, to search for ideas relating to mathematics $(2.14 \%)$ or to practice mathematical skills and procedures $(6.26 \%)$. Hierarchical linear modelling revealed that students that were in mathematical classes with computers generally outperformed those who didn't have computers.

Keywords: educational technology, hierarchical linear modelling, mathematics achievement, TIMSS

Citation: Saal, P. E., van Ryneveld, L., \& Graham, M. A. (2019). The Relationship between using Information and Communication Technology in Education and the Mathematics Achievement of Students. International Journal of Instruction, 12(3), 405-424. https://doi.org/10.29333/iji.2019.12325a 


\section{INTRODUCTION}

Poor student achievement in mathematics has been a great concern for the Department of Basic Education (DBE) in South Africa. The mathematics achievement of South African students ranked among the lowest in several international comparative assessments, for example, in the Trends in International Mathematics and Science Study (TIMSS) 2002, TIMSS 2011 as well as the World Economic Forum (WEF) 2014. It was thus no surprise that TIMSS 2015 found that the average mathematics score of South African students was 376 out of a possible 1000 (Mullis, Martin, Foy \& Hooper, 2016). This shocking result was exacerbated by the context in which the test was taken in South Africa. South Africa participated at a Grade 5 level instead of a Grade 4 level. Reddy et al. (2017) explained that this was done so that "the assessment can serve as a base line against which future results can be compared".

Out of the 48 countries who participated in TIMSS 2015, South Africa ranked secondlast, only outperforming Kuwait (Mullis et al., 2016). What is even more shocking is that only $1 \%$ of South African Grade 5 students performed at the advanced international benchmark level (achieving above 625) and only $4 \%$ at the high international benchmark level (achieving 550 to 625) (Reddy et al., 2017). These results indicated that only a handful of South African Grade 5 students used their skills and knowledge in order to solve complex mathematical problems.

One of the many strategies to improve the mathematics achievement of South African students, included the integration of Information Communication Technology (ICT) in education. This could be due to the fact that some researchers found that using computers in mathematics education might increase students' scores (Bulut \& Cutumisu, 2017; Falck, Mang \& Woessmann, 2018; Ponzo, 2011). However, no literature could be found (to date) on the relationship between the use of computers in primary mathematics education in South Africa and student achievement, based on TIMSS 2015.

\section{PROBLEM STATEMENT AND RATIONALE FOR THE STUDY}

The "White Paper on e-Education" expects teachers to use computers in their classrooms in order to enhance teaching and learning (Department of Education [DoE], 2004). Despite all the efforts, which include, for example, the Teacher Laptop initiative, the Gauteng Online initiative and the Khanya project, initiated by the DoE, it seems that South African mathematics teachers do not fully utilise ICT technology in their classrooms (Mofokeng \& Mji, 2010; Ndlovu \& Lawrence, 2012; Stols et al., 2015). Additionally, Saal (2017) found that $73.9 \%$ of South African students were taught by teachers who were not using computers in mathematics instruction. The rationale of this study was twofold. Firstly, very few South African mathematics teachers use computers in mathematics instruction. For instance, the Second Information Technology in Education Study (SITES) 2006 found that merely 17.95\% of these teachers integrated computers in mathematics instruction (Law, Pelgrum \& Plomp, 2008). Howie and Blignaut (2009) and Saal (2017) also found that South African mathematics teachers mostly used computers for administrative tasks. On the other hand, SITES 2006 found that more than $80 \%$ of Norwegian mathematics teachers implemented computers in their 
classroom instruction. Additionally, more than $80 \%$ of the Singaporean mathematics teachers reportedly used computer applications as a supplement in mathematics instruction (Mullis et al., 2012). Secondly, relating to the rationale of this study, the poor Grade 5 mathematics achievement, in South Africa (see the TIMSS 2015 results), was also one of the reasons this study was conducted. As a result thereof, a quantitative study was conducted in order to investigate how educational technology was used in mathematics teaching and learning. Additionally, the relationship between educational technology and the mathematics achievement, in South Africa, was explored.

Utilising data from TIMSS 2015, this study was guided by the following research questions:

\section{Research Questions}

a) In what way and how often do South African Grade 5 students and their mathematics teachers use ICT in mathematics teaching and learning?

b) How do these teachers perceive the support for integrating ICT in mathematics education?

c) What is the relationship between the use of ICT in mathematics teaching and learning and student performance?

\section{Hypotheses}

The hypotheses of the study are based on the last research question. The hypotheses considered are:

Ho: There is no statistically significant association between the use of educational technology and the mathematics achievement of Grade 5 South African students.

$\mathrm{H}_{1}$ : There is a statistically significant association between the use of educational technology and the mathematics achievement of Grade 5 South African students.

These hypotheses are tested by comparing the p-values of the results against the predictions of the hypotheses. (The $\mathrm{P}$ value, or calculated probability, is the probability of finding the observed results when the null hypothesis $\left(\mathrm{H}_{0}\right)$ of a study question is true.) If the p-value is less than 0.05 , the null hypothesis is rejected and there is a statistically significant association between the use of educational technology and the mathematics achievement of Grade 5 South African students. On the other hand, if the p-value is greater than 0.05 , the null hypothesis is not rejected and, consequently, there is not a statistically significant association between the use of educational technology and the mathematics achievement of Grade 5 South African students.

\section{LITERATURE REVIEW}

In this section, literature on the relationship between the use of educational technology and students' mathematics achievement is discussed.

Literature showed that several researchers analysed data from large international comparative studies, such as the Programme for International Student Assessment 
(PISA) and TIMSS, in order to investigate the relationship between the use of educational technology and student achievement in mathematics (Ayieko, Gokbel \& Nelson, 2017; Bulut \& Cutumisu, 2017; Zhang and Liu, 2016). However, literature showed mixed findings of students' use of educational technology and their mathematics achievement.

For instance, some studies found a positive relationship between the use of educational technology and the mathematics achievement of students (Bulut \& Cutumisu, 2017; Demir \& Kiliç, 2009; Falck, Mang \& Woessmann, 2018; Kubiatko \& Vlckova 2010; Luu \& Freeman, 2011; Ponzo, 2011; Spiezia, 2010). For example, Bulut and Cutumisu (2017) used data obtained from PISA 2012 to determine whether the use of Information Communication Technologies (ICTs) has an impact on the achievement of students in mathematics and science. Focussing on mathematics, their findings showed that students who have computers available at home and school tend to perform better. Similarly, the results of Skryabin, Zhang, Liu and Zhang (2015) and Petko, Cantieni and Prasse (2017) showed a significant positive relationship between students who used computers at home and their mathematics achievement.

In addition, their findings show that students need to use computers more regularly (every, or almost every, day) in order to outperform students who seldom (once a month) use computers (Wittwer \& Senkbeil, 2008). This finding is on par with the findings of Skryabin et al. (2015) who found that the more frequently Grade 8 students used computers at home, especially for schoolwork, the better their mathematics achievement. The use of computers at home could also have provided students with a more interactive approach in understanding mathematical concepts in a virtual setting which could have resulted in better mathematics scores (Kul, Celik \& Aksu, 2018).

However, some researchers found negative relationships between these variables (Ayieko et al., 2017; Eickelmann, Gerick \& Koop, 2017; Kruger, 2018; Zhang \& Liu, 2016). Ayieko et al. (2017) analysed data from TIMSS 2011 in order to investigate the relationship between computer use and students' scores in mathematics in Taiwan, Singapore and Finland. The authors found that when students in Taiwan used computers at their homes as well as in school, they tended to have lower mathematics reasoning scores. In another study, Eickelmann et al. (2017) used the PISA 2012 datasets of five countries, in order to explore the relationship between using ICTs in mathematics instruction and Grade 9 student achievement. One of their findings indicated a negative relationship concerning the use of computers for tasks such as "drawing the graph of a function, constructing geometric figures, entering data in a spreadsheet and finding out how the graph of a function like $y=\mathrm{ax}^{2}$ changes depending on a" (Eickelmann et al., 2017 , p. 14). This implied that, the more students used computers for those selected activities, the worse they performed (this was found for Germany and the Netherlands). Their findings also stated that German students, with an exemplary student to computer ratio, and where computers were often used in mathematics instruction, performed worse than their counterparts. In a similar study, Kruger (2018) investigated the relationship between the investment in ICT in South African schools and the mathematics achievement of Grade 9 students, based on TIMSS 2011 and TIMSS 2015. 
The author found that the South African students' achievement was worse if they used computers regularly to search for mathematical principles, including concepts, and if they practised mathematics skills and procedures on computers, than their counterparts who did not regularly make use of computers for these tasks. These students also achieved lower mathematics scores if they often used computers to search for ideas and information and if they often processed and analysed data on the computer. Ayieko et al. (2017) found similar results in Singapore, i.e., the more teachers allowed students to process and analyse data on a computer, the lower their mathematics scores were. Focussing on the frequent use of computers in South Africa, Kruger (2018) found that the more often students used computers at home, the lower their mathematics results. Similarly, Ponzo (2011) and Zhang and Liu (2016) found that students who used computers at school almost every day achieved lower mathematics scores.

\section{CONTEXT FOR THE STUDY}

The context of the study is the stated intention of the South African Government to deploy tablet computer devices to all school children in South Africa by 2025 (De Villiers, 2019). The focus of this paper is on all nine provinces of South Africa. South Africa's education system consists of three levels namely; the General Education Training Phase (reception to Grade 9), The Further Education and Training Phase (Grade 10 to 12) and the Higher Education Phase (certificates, diplomas, degrees up to doctorate level). The focus of this study is on the General Education Training Phase, specifically Grade 5.

In 2015, there were approximately 25720 public and private schools with the majority of these (more than 95\%) being public schools (Department of Basic Education [DBE], 2015b). The student population was approximately 12.8 million. A total of 416013 principals and teachers were employed in public and private schools, respectively (DBE, 2015a). The DBE stated, in their five-year strategic plan 2015/2016-2019/2020, that access to educational technology was a crucial requirement to advance the teaching and learning process (DBE, 2015b).

\section{METHOD}

\section{Research Design}

To investigate how ICT was used in mathematics teaching and learning, the researcher conducted a secondary data analysis of TIMSS 2015 data. A quantitative approach was followed in order to investigate the relationship between the use of information and communication technology (independent variables) and mathematics achievement (dependant variable) of Grade 5 students. The philosophical worldview adopted in the study is post-positivism. The latter derived from the positivist theory whereby positivist believes that the "scientific method produces precise, verifiable, systematic and theoretical answers to the research question" (Leedy \& Omrod, 2010, p 55). The latter was rejected because it is very difficult to attain precise answers to research questions in the social sciences. Consequently, the post-positivism theory was selected since postpositivists assume that the absolute truth can never be found (Millan, 2012). If a researcher can never find the absolute truth, it indicates that the findings will in most 
cases be imperfect. Additionally, ex post facto educational research was carried out as the variables were outside the researcher's control. The TIMSS database is typically used for conducting ex post facto educational research (Cohen, Manion \& Morrison, 2017).

\section{Participants}

As mentioned earlier, a total of 48 countries participated in TIMSS 2015 (Mullis et al., 2016). TIMSS assessed the mathematics and science achievement of Grade 4 and Grade 8 students (LaRoche, Joncas \& Foy, 2016). Participating countries could administer the assessment to their Grade 5 and Grade 9 students instead of their Grade 4 and Grade 8 students (LaRoche \& Foy, 2016). Additionally, countries could also participate in TIMSS Numeracy (at Grade 4 level), which is an easier version of the TIMSS assessment (LaRoche et al., 2016). As mentioned previously, South Africa participated at a Grade 5 level. The latter administered the TIMSS Numeracy assessment to Grade 5 students to allow "more time for appropriate interventions to be introduced into the schooling system" (Reddy et al., 2016).

TIMSS 2015 employed a stratified two-stage cluster sample design (LaRoche et al., 2016). During the first sampling stage (sampling of schools), the National Research Coordinators (NRCs) of each country provided Statistics Canada with a list of schools, also referred to as the sample frame (LaRoche \& Foy, 2016). Thereafter, schools were sampled according to their size. In the case of South Africa, very small schools (measure size of $<8$ ) as well as special needs schools were excluded (LaRoche et al., 2016). The sample frame was then stratified. This was done in order to "improve the efficiency of the sample design, thereby making survey estimates more reliable" and also to "ensure proportional representation of specific groups of schools in the sample" (LaRoche et al., 2016, p.3.12). In South Africa the schools were sorted based on school type, the socioeconomic status (SES) of the school, province, performance level and region as outlined in Table 1 (LaRoche et al., 2016; Reddy et al., 2017). Even though small schools and special schools were excluded in this study, the sample is representative of the public and independent schools in South Africa. 
Table 1

Sampling Procedure of Grade 5 Schools in South Africa

\begin{tabular}{|c|c|c|c|}
\hline \multicolumn{2}{|c|}{ Population } & \multicolumn{2}{|r|}{ Sample } \\
\hline School & Students & School & Students \\
\hline 16194 & 924392 & 298 & 10932 \\
\hline \multicolumn{4}{|c|}{ Stratification of sample frame } \\
\hline \multicolumn{2}{|c|}{ Explicit strata } & & \multirow[t]{2}{*}{ Implicit strata } \\
\hline School type & $\begin{array}{l}\text { Socio economic } \\
\text { status }\end{array}$ & $\begin{array}{l}\text { Total schools } \\
\text { sampled }\end{array}$ & \\
\hline \multirow{2}{*}{$\begin{array}{l}\text { Independent } \\
\text { schools }\end{array}$} & Low fee & 27 & \multirow{13}{*}{$\begin{array}{l}\text { Performance level } \\
\text { (Lower quintiles, Mid quintiles } \\
\text { and higher quintiles) }\end{array}$} \\
\hline & Medium-high fee & 12 & \\
\hline \multirow[t]{10}{*}{ Public } & Province & & \\
\hline & Eastern Cape & 29 & \\
\hline & Free State & 28 & \\
\hline & Gauteng & 28 & \\
\hline & KwaZulu Natal & 30 & \\
\hline & Limpopo & 30 & \\
\hline & Mpumalanga & 28 & \\
\hline & Northern Cape & 28 & \\
\hline & North West & 28 & \\
\hline & Western Cape & 30 & \\
\hline Total & & 298 & \\
\hline
\end{tabular}

Adapted from LaRoche et al. (2016).

At the second stage, the NRCs sampled intact classes of students since "TIMSS pays particular attention to students' curricular and instructional experiences, and these typically are organized on a classroom basis" (Johansone, 2016; LaRoche \& Foy, 2016, p.3.1). If the sampled school agreed to participate, the NRCs requested the number of mathematics classes and teachers and captured the information in the Win W3S database (Martin \& Mullis, 2012, Johansone, 2016). It should be noted that although the sampling methodology, followed by TIMSS 2015, is a complex procedure, TIMSS is designed to provide valid and reliable measurements of trends in student achievement around the world (LaRoche et al., 2016). Datasets for South Africa were retrieved from the IEAs TIMSS 2015 study data repository in SPSS format. Grade 5 mathematics teachers and principals from 298 primary schools in South Africa as well as 10932 Grade 5 students were included in this study.

\section{Data Collection and Instruments of TIMSS 2015}

Data was collected in South Africa from October to December 2014 (Johansone, 2016; Reddy, et al., 2017). The research staff of TIMSS and the PIRLS International Study Center at Boston College and other stakeholders designed curriculum, school, teacher, student and home background questionnaires which were completed by the NRCs, principals, teachers, students and their parents or guardians, respectively (Arora \& Stanco, 2012, Mullis et al., 2016; Mullis, Drucker, Preuschoff). The assessment booklet contained fourteen mathematics and fourteen science items (Johansone, 2016; LaRoche et al., 2016). Using the WinW3S software, an assessment booklet was systematically 
assigned to each learner (Johansone, 2016). Students had to complete the assessment in 36 minutes with a break of 30 minutes between the sections (Mullis et al., 2016). All instruments were labeled, linking the data between the school, classes, students and teachers (Johansone, 2016).

\section{Data Analysis}

Both descriptive and inferential statistics were employed to analyse data obtained from TIMSS 2015. The International Database Analyser Software (IDB) version 3.0 was used to obtain descriptive statistics that included percentages and means. For inferential statistics, the hierarchical linear model (HLM) version 7 statistical program was used to perform the analysis. Table 2 outlines the variables used in this study.

Table 2

Summary of Student and School Variables

\begin{tabular}{|c|c|c|}
\hline \multicolumn{3}{|c|}{ Independent variables } \\
\hline Variable & Variable description & Index \\
\hline ASBG05A & The students' own Computer/tablet & \multirow{4}{*}{$\begin{array}{l}\text { Reported by } \\
\text { student }\end{array}$} \\
\hline ASBG10A & Students' use of computer or tablet at home for schoolwork & \\
\hline ASBG10B & Students' use of computer or tablet at school for schoolwork & \\
\hline ASBG10C & Students' use of computer or tablet at other places for schoolwork & \\
\hline ASBH15 & $\begin{array}{l}\text { Digital devices at home (computers, tablets, smartphones, smart } \\
\text { TVs and e-readers) }\end{array}$ & $\begin{array}{l}\text { Reported by parent } \\
\text { or guardian }\end{array}$ \\
\hline ACBG03A & Economically disadvantaged homes & \multirow{2}{*}{$\begin{array}{l}\text { Reported by } \\
\text { principal }\end{array}$} \\
\hline ACBG14AH & Computer technology for teaching and learning & \\
\hline ATBG08F & Adequate technological resources & \multirow{8}{*}{$\begin{array}{l}\text { Reported by } \\
\text { mathematics } \\
\text { teacher }\end{array}$} \\
\hline ATBM05A & Computers/tablets during mathematics lesson & \\
\hline ATBM05BA & Each student has computer in class & \\
\hline ATBM05BC & The class has computers that students share & \\
\hline ATBM05CA & Use of computers to practise skills and procedures & \\
\hline ATBM05CB & Use of computers to explore principals and concepts & \\
\hline ATBM05CC & Use of computers to look up ideas & \\
\hline ATBM09D & $\begin{array}{l}\text { Professional development for integrating information technology } \\
\text { into mathematics }\end{array}$ & \\
\hline \multicolumn{3}{|c|}{ Dependent variable } \\
\hline ASMMAT01 & $1^{\text {st }}$ plausible value mathematics & \multirow{5}{*}{$\begin{array}{l}\text { Student } \\
\text { mathematics } \\
\text { achievement scores }\end{array}$} \\
\hline ASMMAT02 & $2^{\text {nd }}$ plausible value mathematics & \\
\hline ASMMAT03 & $3^{\text {rd }}$ plausible value mathematics & \\
\hline ASMMAT04 & $4^{\text {th }}$ plausible value mathematics & \\
\hline ASMMAT05 & $5^{\text {th }}$ plausible value mathematics & \\
\hline
\end{tabular}

\section{Reliability and Validity}

Every TIMSS assessment has been conducted in a similar consistent way for the past twenty years (Johansone, 2016). This implies that the same procedures were followed during every cycle. TIMSS 2015 also included items from the previous round (TIMSS 2011) to ensure reliable measurement (Mullis et al., 2016). Assessment reliability was further enhanced through the development of a large pool of items. The Cronbach's Alpha test was employed to measure consistency in all context questionnaire items (Foy et al., 2016). The reliability coefficients were calculated for all countries. It should also be noted that TIMSS 2015 ensured construct validity by applying item analysis (Mullis 
et al., 2016). The credibility of this study was ensured by reporting on both positive and negative results.

\section{FINDINGS}

This section firstly explains how Grade 5 students and their mathematics teachers use educational technology and the extent to which teachers have support the integration of educational technology in mathematics teaching. Secondly, multi-level models of the relationships between educational technology at school and student level and the mathematics achievement of students are discussed.

\section{Descriptive Statistics}

Firstly, the SES of the schools was considered. The question, regarding SES in the TIMSS questionnaire, was phrased as "Approximately what percentage of students in your school come from economically disadvantaged homes?" The options were ' $0 \%$ to $10 \%$ ', ' $11 \%$ to $25 \%$ ', ' $26 \%$ to $50 \%$ ' and 'more than $50 \%$ '. In South Africa, principals from 298 schools responded to this question. For the categories ' $0 \%$ to $10 \%$ ', ' $11 \%$ to $25 \%$ ', ' $26 \%$ to $50 \%$ ' and 'more than $50 \%$ ' the percentage responses were $8.43 \%$, $2.66 \%, 16.76 \%$ and $72.13 \%$, respectively. It is alarming to note that the majority $(72.13 \%)$ of the principals indicated that more than $50 \%$ of their students come from economically disadvantaged homes. Students enrolled at these schools achieved an average mathematics score of 357.33, which was below the international average (500 points) of TIMSS 2015. The average mathematics scores for the remaining three categories were also below the international average.

Results showed that the majority $(38.61 \%)$ of principals indicated that a shortage of computer technology for teaching and learning affected their school's instruction negatively. On the other hand, $29.65 \%$ of principals indicated their schools instruction was not affected by a shortage of computer technology. Approximately $33.52 \%$ of the principals indicated that their school's instruction was somewhat negatively affected by a shortage of computer technology. Findings showed that $89.78 \%$ of the students were taught by teachers who did not have computers or tablets available for use during mathematics lessons. On the other hand, only $10.21 \%$ of the students were taught by teachers who had computers available during mathematics lessons. Students who were taught by teachers who had computers available during mathematics lessons achieved an average mathematics achievement score of 431.68 while those who were taught without computers achieved an average mathematics score of 371.08, lower than their counterparts.

Only $23.91 \%$ of the students had their own computers, in the case where the teacher used computers in mathematics lessons. These students achieved a higher mathematics average (468.00) than those who did not have their own computers (435.41). Teachers indicated that a total of $89.85 \%$ of students were taught in a mathematics classroom where they had to share computers. These students achieved a higher mathematics average of 543.02 whereas the students who did not share computers achieved a mathematics average score of 433.88 . The findings showed that less than $10 \%$ of the students were taught by teachers who used computers 'every, or almost every, day' in 
their classroom instruction to look up ideas, to practice skills and procedures or to explore concepts in mathematics. Students who were taught by teachers who 'never, or almost, never' used computers to look up ideas and to practice skills achieved higher mathematics averages than those who were taught by teachers who used computers 'every, or almost every, day' for these selected activities (see Table 3). On the other hand, students taught by teachers who used computers every day or almost every day to explore concepts on the computer achieved slightly higher mathematics scores than those who 'never or almost never' used computers.

Table 3

Frequency of the Use of Computers for Certain Mathematics Activities by the Teachers and the Average Mathematics Achievement of Students

\begin{tabular}{lllll}
\hline & $\begin{array}{l}\text { Every or } \\
\text { almost } \\
\text { every day }\end{array}$ & $\begin{array}{l}\text { Once or } \\
\text { twice } \\
\text { a week }\end{array}$ & $\begin{array}{l}\text { Once or } \\
\text { twice } \\
\text { a month }\end{array}$ & $\begin{array}{l}\text { Never or } \\
\text { almost } \\
\text { never }\end{array}$ \\
\hline Look up ideas on the computer & 348.06 & 433.02 & 496.76 & 401.12 \\
\hline $\begin{array}{l}\text { Practice skills and procedures on } \\
\text { the computer }\end{array}$ & 378.61 & 460.35 & 514.58 & 383.66 \\
\hline Explore concepts on the computer & 438.40 & 461.61 & 479.49 & 410.86 \\
\hline
\end{tabular}

Teachers were also asked to indicate whether the school had computers which could be used for teaching and learning. Only $13.89 \%$ of the students were taught by teachers where the school had computers available for the use of the students. This refers to a computer laboratory or a computer room. Consequently, $86.10 \%$ of the students were taught by teachers who did not have computers at their schools. The majority (37.99\%) of the teachers reported that they had serious problems with the adequacy of technological resources. This meant that these teachers had a shortage or no technological resources. On the other hand, only $17.83 \%$ of teachers had no problems with adequate technological resources. It was interesting to note that students who were taught by teachers with serious problems in terms of technological resources achieved an average mathematics achievement score of 344.87 while students who were taught by teachers with no problems with regards to technological resources achieved a higher average mathematics achievement score of 442.20.

Focussing on support for using educational technology, we found that the majority of students $(33.53 \%)$ were taught by teachers who had serious problems with getting adequate support for integrating educational technology. Adequate support in this context implies that teachers do get support to an extent but it is just not satisfactory. Only $16.30 \%$ of students were taught by teachers who had no problems with adequate support for integrating educational technology. Students who were taught by these teachers had an average mathematics achievement of 460.03, while students who were taught by teachers who had serious problems with adequate support achieved an average mathematics score of 336.84 . Results also showed that the majority $(61.75 \%)$ of the mathematics teachers did not attend professional development for integrating IT in mathematics education. Only $38.24 \%$ of teachers reportedly attended professional development for this purpose. 
Next, we concentrated on the extent of students' information and communication technology use. Students reported that they used computers or tablets at school, home and other places for school work (see Table 4). Findings showed that the majority (38.71\%) of students use computers 'every, or almost every, day' at home for schoolwork purposes. Most of the students reported that they 'never, or almost never' used computers at school $(51.21 \%)$ or at other places $(40.91 \%)$ for schoolwork purposes.

Table 4

Extent of Students' use of Computers or Tablets at Home, School and Other Places for Schoolwork

\begin{tabular}{llllc}
\hline & $\begin{array}{l}\text { Every or } \\
\text { almost } \\
\text { every day }\end{array}$ & $\begin{array}{l}\text { Once or } \\
\text { twice } \\
\text { a week }\end{array}$ & $\begin{array}{l}\text { Once or } \\
\text { twice } \\
\text { a month }\end{array}$ & $\begin{array}{l}\text { Never or } \\
\text { almost } \\
\text { never }\end{array}$ \\
\hline Percentage & & & & \\
\hline $\begin{array}{l}\text { Computers for } \\
\text { schoolwork at home }\end{array}$ & 38.71 & 17.91 & 7.52 & 35.84 \\
\hline $\begin{array}{l}\text { Computers for } \\
\text { schoolwork at school }\end{array}$ & 23.65 & 14.74 & 8.38 & 51.21 \\
\hline Computers for schoolwork at other places & 22.26 & 20.68 & 16.14 & 40.91 \\
\hline
\end{tabular}

Results indicated that the majority $(76.07 \%)$ of students had digital devices at home which included computers, tablets, smartphones, smart TVs and e-readers. While $23.9 \%$ reported that they did not have digital devices at home, the majority $(68.57 \%)$ did not have their own computer or tablet. On the other hand, $23.91 \%$ of the students indicated that they owned a computer or tablet. Results also showed that most $(64.36 \%)$ students did not have internet connection at home, while $35.6 \%$ of students indicated that they had an internet connection at home.

\section{Inferential Statistics}

In this section, the HLM results are discussed. The TIMSS 2015 data contained a lot of missing values. As a result, thereof, the maximum likelihood with expectation maximization (EM) algorithms was employed to replace the missing values; see Butakor (2015) for a motivation as to why the EM algorithm was used to replace missing values as opposed to, say, listwise or pairwise deletion. "TIMSS data are cross-sectional by nature" and therefore longitudinal data were not available (Nilsen, Gustafsson \& Blömeke, 2016, p. 13). As mentioned previously students are nested within classes and classes are nested within schools. Consequently, only the SES of the schools was controlled. Three HLM analyses were conducted. Firstly, the null model was created which did not contain any variables. It showed how much the difference in the mathematics achievement (outcome variable) within/between schools was. Table 5 outlines the results of the null model. The variance of the null model is $57.84 \%$. Furthermore, the variance at level 2 (principal and teacher) is significantly different from zero, since the p-value is less than 0.05 (p-value $<0.001)$. 
Table 5

The Null Model

\begin{tabular}{llllll}
\hline & $\begin{array}{l}\text { Standard } \\
\text { Deviation }\end{array}$ & $\begin{array}{l}\text { Variance } \\
\text { Component }\end{array}$ & df & Chi-square & p-value \\
\hline INTRCPT1,u0 & 78.28 & 6127.80 & 296 & 11668.87 & $0.000^{*}$ \\
\hline Level-1, r $\quad 69.49$ & 4830.18 & & & \\
\hline
\end{tabular}

*Significant at a $5 \%$ level of significance

Secondly, the full model was created with both level 1 (student) and level 2 (principal and teacher) variables. This step was included in order to investigate the relationship between these variables and the mathematics achievement of students. Table 6 shows the results of the full model with a variance of $37.29 \%$. Additionally, the results show significance at level 2.

Table 6

The Full Model

\begin{tabular}{llllll}
\hline & $\begin{array}{l}\text { Standard } \\
\text { Deviation }\end{array}$ & $\begin{array}{l}\text { Variance } \\
\text { Component }\end{array}$ & df & Chi-square & p-value \\
\hline INTRCPT1,u0 & 51.22757 & 2624.26431 & 275 & 11668.86563 & $0.000^{*}$ \\
\hline Level-1, r $\quad 69.49953$ & 4830.18404 & & &
\end{tabular}

*Significant at a $5 \%$ level of significance

Thirdly, the parsimonious model (also referred to as the final model) was created. In this model all the insignificant variables were removed one at a time, till only significant variables remained. Table 7 shows the results of the parsimonious model.

Table 7

Summary Results of the Parsimonious Model

\begin{tabular}{llllll}
\hline Random Effect & $\begin{array}{l}\text { Standard } \\
\text { Deviation }\end{array}$ & $\begin{array}{l}\text { Variance } \\
\text { Component }\end{array}$ & df & Chi-square & p-value \\
\hline INTERCPT, u0 & 55.73 & 3106.76 & 288 & 7765.004 & $0.000^{*}$ \\
\hline LEVEL-1 & 66.82 & 4465.65 & & & \\
\hline
\end{tabular}

*Significant at a 5\% level of significance

The variance at the student level is 4465.65 , which represents $59 \%$ of the total variance. The variance at school level (teacher and principal) is 3106.76 that represent $41 \%$ of the total variance which is statistically significant ( $\mathrm{p}$-value $<0.001)$. The average reliability estimate was 0.95 indicating that sample averages reflected the true school means. Table 8 shows the coefficients of the significant predictors of the parsimonious model. 
Table 8

The Significant Predictors of the Parsimonious Model

\begin{tabular}{|c|c|c|c|c|}
\hline & Coefficient & $\begin{array}{l}\text { Standard } \\
\text { Error }\end{array}$ & $\begin{array}{l}\text { Approx. t- } \\
\text { ratio }\end{array}$ & p-value \\
\hline Intercept & 385.05 & 4.67 & 82.39 & $0.000 *$ \\
\hline \multicolumn{5}{|l|}{ Level 1 (Student predictors) } \\
\hline Student's Own Computer/tablet & -17.03 & 2.92 & 5.82 & $0.000 *$ \\
\hline $\begin{array}{l}\text { Frequent use of computer/tablet for schoolwork } \\
\text { at home }\end{array}$ & -2.57 & 1.17 & 2.19 & $0.033 *$ \\
\hline $\begin{array}{l}\text { Frequent use of computer/tablet for schoolwork } \\
\text { at school }\end{array}$ & -13.72 & 1.25 & 10.97 & $0.000 *$ \\
\hline $\begin{array}{l}\text { Frequent use of computer/tablet for schoolwork } \\
\text { at some other place }\end{array}$ & -2.09 & 0.98 & 2.14 & $0.033 *$ \\
\hline $\begin{array}{l}\text { Digital devices at home (computers, tablets, } \\
\text { smartphones, smart TVs and e-readers) }\end{array}$ & 8.67 & 1.47 & 5.89 & $0.000 *$ \\
\hline \multicolumn{5}{|l|}{ Level 2 (School predictors) } \\
\hline Adequate technological resources & 15.39 & 4.54 & -3.39 & $0.001 *$ \\
\hline Computers/tablets during mathematics lesson & 38.01 & 13.10 & -2.90 & $0.004 *$ \\
\hline Each student has a computer in class & 82.03 & 23.35 & -3.51 & $0.001 *$ \\
\hline The class has computers that students share & 90.11 & 16.45 & -5.48 & $0.000 *$ \\
\hline Use of computers to look up ideas & -37.64 & 8.68 & 4.34 & $0.000 *$ \\
\hline $\begin{array}{l}\text { Professional development - integrating } \\
\text { information technology into mathematics }\end{array}$ & 42.15 & 10.54 & -4.00 & $0.000 *$ \\
\hline Economically disadvantaged homes & 34.24 & 6.10 & -5.6 & $0.000 *$ \\
\hline Computer technology for teaching and learning & -10.18 & 4.16 & 2.45 & $0.015^{*}$ \\
\hline
\end{tabular}

*Significant at a $5 \%$ level of significance

Focussing on student predictors:

- With regards to the frequency of computer use, results show that students who owned a computer or tablet achieved lower mathematics scores than the students who did not have these devices $(\beta=-17.03$, p-value $<0.001)$; and

- $\quad$ Students that used computers at home $(\beta=-2.57$, p-value $<0.001)$, school $(\beta=$ 13.72, $\mathrm{p}$-value $<0.001)$ and other places $(\beta=-2.09$, p-value $<0.001)$ for schoolwork more frequently (every, or almost every, day) tended to have lower mathematics scores than students who 'never, or almost never' used computers.

The surprising second result could be because the use of computers/tablets was diverting the students from focusing on mathematics. For example, one of the students from the study of Semerci (2018) indicated that "The distribution of the tablets had a negative effect, and I regret to say that I could [sic] not able to stop playing game [ sic] for hours both at school and at home" (p. 109-110).

Finally, with regards to the total digital devices at home, findings indicate that students with more digital devices at home $(\beta=8.67, p$-value $<0.001)$ tend to outperform students with no digital devices. This could be because students with more digital devices have access to more resources such as the internet to assist them with mathematics related tasks (Abdelfattah \& Lam, 2018).

Concentrating on school predictors, findings indicate that: 
- $\quad$ Students who were taught by teachers who indicated that they had no problems with adequate technological resources $(\beta=15.39, \mathrm{p}$-value $<0.001)$ outperformed students who were taught by teachers who had serious problems with adequate technological resources;

- $\quad$ Students taught by teachers who made use of computers in mathematics lessons $(\beta=38.01$, $\mathrm{p}$-value $<0.001)$ achieved higher mathematics scores than students who were taught without computers during mathematics lessons; Likewise, students who had their own computer $(\beta=82.03$, $\mathrm{p}$-value $<0.001)$ or shared a computer $(\beta=90.11$, $\mathrm{p}$-value < $0.001)$ during mathematics lessons achieved higher mathematics scores than students who did not have computers at all;

- Students taught by teachers who let them use computers 'every or almost every day' to look up ideas ( $\beta=-37.64$, $p$-value $<0.001)$ in mathematics achieved lower scores than students who 'never or almost never' used computers to look up ideas;

- Additionally, the students who were taught by teachers who attended professional development for integrating IT in mathematics $(\beta=42.15$, $p$-value $<0.001)$ achieved higher mathematics achievement scores than the students who were taught by teachers who did not attend professional development for integrating IT in mathematics;

- $\quad$ Furthermore, students enrolled at schools that accommodated less than $10 \%$ of students from economically disadvantaged homes $(\beta=34.24$, $p$-value $<0.001)$ achieved higher mathematics scores than schools which hosted more than $50 \%$ of students from economically disadvantaged homes;

- $\quad$ Surprisingly, students from schools where instruction was not affected at all by a shortage of computer technology for teaching and learning $(\beta=-10.18$, $p$-value $<0.001)$ achieved lower mathematics average scores than students who are from schools where instruction is affected a lot by a shortage of computer technology for teaching and learning.

\section{DISCUSSION}

The aim of this study was to determine the relationship between the use of information and communication technology and mathematics achievement in South Africa at schooland student level. The first research question of the study was: 'For what purposes, and to what extent do South African Grade 5 students and their mathematics teachers use information and communication technology in mathematics teaching and learning?'

Focussing at school level, to answer this research question we first had to look at the availability of information and communication technology and the socio-economic status of the schools. Results showed that most of the schools accommodated students from economically disadvantaged homes. We also found that more than $85 \%$ of the students were taught by teachers who indicated that the school did not have any computers that the class could sometimes use for mathematics teaching and learning. Consequently, teachers who had serious problems with the adequacy of technological resources taught the majority of the students. The majority of principals also indicated that their school's instruction was affected negatively if there was a shortage of computer technology for teaching and learning. Focussing on computers in the mathematics classroom, we found that mathematics teachers who did not have 
computers available during mathematics lessons taught almost $90 \%$ of the students. Less than $30 \%$ of the students were taught by teachers where they had they own computers in the mathematics classroom. On the other hand, the few teachers $(10 \%)$ who had computers in their mathematics classrooms had their students use the computers to look up ideas, to practice skills and procedures plus to explore concepts in mathematics. Teachers who used computers 'every, or almost every, day' for these selected mathematics activities taught less than $10 \%$ of the students. Teachers who 'never or almost never' used computers for those selected mathematics activities taught the majority of the students.

Focussing on the student level, we found that most students had digital devices at home. However less than $30 \%$ of students owned a computer or tablet. The majority of the students also reported that they did not have an internet connection. We also found that students used computers at home, school and other places for schoolwork. Results showed that most of the students 'never or almost never' used computers for schoolwork at school or at other places. Most of the students indicated that they used computers at home for schoolwork.

The second research question was: 'How do the mathematics teachers perceive the support they are getting for integrating information and communication technology in mathematics education?' Results showed that most of the students were taught by teachers who had serious problems with the adequacy of support for integrating technology in mathematics teaching. We found that less than $20 \%$ of the students were taught by teachers who indicated that they did not have any problems with the adequacy of support for integrating technology in mathematics education.

Let us now focus on the third research question, 'What is the relationship between the use of educational technology in mathematics teaching and learning and the student performance?'

At school level, students enrolled at schools with adequate technological resources and where students have their own or share computers during mathematics lessons achieved higher mathematics results. The results of Eickelmann et al. (2017) differ from our finding, stating that students who attended schools in Germany with similar conditions such as the availability of computers and an exemplary computer to student ratio performed worse than their counterparts.

We found that only the use of computers to look up ideas had a significant negative relationship with the mathematics achievement of students. This means that the more students used computers to look up ideas in mathematics the worse their performance was. This finding is supported by Kruger (2018) who found that the more frequent students used computers to search for ideas in mathematics the worse their mathematics achievement. This negative relationship could be explained by the fact that students relied too much on computers to search for ideas in mathematics. Students who were taught by teachers who recently attended professional development for integrating IT in mathematics education performed better. This could mean that these teachers applied the skills and knowledge that they acquired during the professional development session 
in their own classrooms. This finding is in line with the findings of Ayieko et al. (2017) who found that students' mathematics scores in Finland and Taiwan are better when their teachers get the necessary support. The picture looks different in Singapore where Ayieko et al. (2017) found that the students who were taught by teachers who received support for integrating IT in mathematics performed worse than their counterparts.

At student level, results showed significant negative relationships when students used computers 'every, or almost every, day' at their homes, at school and other places for schoolwork. Students who used computers at these venues more frequently performed worse than students who 'never or almost never' used computers at home, school and other places for schoolwork. These results are in line with the findings of Kruger (2018) who found that the more frequently students used computers for those selected activities the lower their mathematics results were. The negative relationship between the use of computers at school, at home and other places could be a result of incompatible education software (Kruger, 2018). These results are also on par with the findings from Bulut and Cutumisu (2017) who found that the frequent use of ICTs at home for schoolwork resulted in lower mathematics scores.

Based on the results discussed, a significant relationship was found between the use of between educational technology in mathematics and the mathematics achievement of Grade 5 students in South Africa.

\section{CONCLUSION}

The use of educational technology in South Africa was investigated, more specifically, how students and teachers used educational technology and whether there was a relationship between the use of educational technology in mathematics and the mathematics achievement of Grade 5 students. It was found that the use of educational technology is related to the mathematics achievement of students. This study also contributes to new knowledge regarding the use of educational technology in South Africa. This study provides policymakers with valuable information regarding: the accessibility of educational technology in schools, the availability and capacity of educational technology, support for integrating educational technology (professional development, technologically competent staff and policies) as well as the use of educational technology in the classroom. The findings of this study might be used to develop strategies to support educational technology integration in mathematics education.

One of the limitations of this study was that we used secondary data and were limited to the instruments (e.g. questionnaires) used in the original TIMSS dataset. Consequently, we could not add extra variables. Therefore, we recommend that future researchers use a qualitative approach to elaborate on the findings of this study. Just deploying computer technology to all the learners will not solve the challenges of mathematics performance, but it is very important to consider the skills level and training of the teachers who have to guide the learners in the use of the technology. For example, we found that teachers have serious problems with the adequacy of computer technology for teaching and learning as well as with support for integrating computers in their classrooms. Interviews 
might provide more detail on the matter. Interviews might also explain why most teachers did not attend professional development. We also recommend that future studies need to focus on the needs, competencies and perceptions of Grade 5 mathematics teachers regarding the use of educational technology since teachers play a vital role in the integration of these technologies in teaching and learning.

\section{Funding}

This work was supported by the Deutscher Akademischer Austausch Dienst and National Research Foundation [grant number: DAAD160728182965] as well as the University of Pretoria.

\section{REFERENCES}

Abdelfattah, F., \& Lam, J. (2018). Linking homework to achievement in mathematics: An examination of 8th grade Arab participation in TIMSS 2015. International Journal of Instruction, 11(4), 607-624.

Ayieko, R. A., Gokbel, E. N., \& Nelson, B. (2017). Does computer use matter? The influence of computers on students' mathematics reasoning. FIRE: Forum for International Research in Education, 4(1), 67-87.

Bulut, O., \& Cutumisu, M. (2017). When technology does not add up: ICT use negatively predicts mathematics and science achievement for Finnish and Turkish students in PISA 2012. In EdMedia: World Conference on Educational Media and Technology (pp. 935945). Association for the Advancement of Computing in Education (AACE). Retrieved from https://sites.ualberta.ca/ cutumisu/publications/2017/2017EdMedia_BulutCutumisu.pdf

Butakor, P. K. (2015). Multilevel modeling of factors that influence mathematics achievement in Ghana: A secondary analysis of TIMSS 2007 and 2011. (Unpublished, doctoral dissertation). University of Alberta, Canada.

Cohen, L., Manion, L., \& Morrison (2017). Research methods in education ( $8^{\text {th }}$ ed.). London: Routledge.

Creemers, B. P. (1994). Effective instruction: An empirical basis for a theory of educational effectiveness. In D. Reynolds, B. P. M. Creemers, P. S. Nesselrodt, E. C. Schaffer, S. Stringfield, C. Teddlie (Ed.), Advances in school effectiveness research and practice (pp. 189-205). Oxford: Pergamon.

Demir, I., \& Kiliç, S. (2009). Effects of computer use on students' mathematics achievement in Turkey. Procedia - Social and Behavioral Sciences, 1(1), 1802-1804.

Department of Basic Education. (2015a). 2015 School Realities. Retrieved from https://www.education.gov.za/Portals/0/Documents/Reports/School\%20realities\%20201 5.pdf?ver=2016-04-22-134204-903

Department of Basic Education. (2015b). Five-year strategic plan 2015/20162019/2020. Retrieved from https://www.gov.za/sites/default/files/gcis_document/201606/dbe-strategic-plan-march2016.pdf 
Department of Education. (2004). White Paper on e-Education: Transforming Learning through Information and Communication Technologies (ICTs). (Notice 1869 of 2004). Government Gazette. (No.26762). Pretoria: Department of Education.

De Villers J. (2019). 17 Key Announcements in the State of the Nation Address, including the new eVisa and Free Tablets. Business Insider South Africa. 7 February, 2019. Retrieved from https://www.businessinsider.co.za/key-announcements-inramaphosas-state-of-the-nation-address-2019-2 Accessed 8 February 2019.

Eickelmann, B., Gerick, J., \& Koop, C. (2017). ICT use in mathematics lessons and the mathematics achievement of secondary school students by international comparison: Which role do school level factors play? Education and Information Technologies, 22(4), 1527-1551.

Falck, O., Mang, C., \& Woessmann, L. (2018). Virtually no effect? Different uses of classroom computers and their effect on student achievement. Oxford Bulletin of Economics and Statistics, 80(1), 1-38.

Foy, P., Martin, M. O., Mullis, I. V. S., Yin, L., Centurino, V. A. S., \& Reynolds, K. A. (2016). Reviewing the TIMSS 2015 achievement item statistics. In Martin, M. O., Mullis, I. V. S, \& Hooper, M. (Ed.), Methods and procedures in TIMSS 2015 (pp. 11.11-11.43). Chestnut Hill, MA: TIMSS \& PIRLS International Study Center, Lynch School of Education, Boston College. Retrieved from https://timss.bc.edu/publications/timss/2015-

methods/T15_MP_Chap11_Reviewing_Achievement.pdf

Howie, S. J., \& Blignaut, A. S. (2009). South Africa's readiness to integrate ICT into mathematics and science pedagogy in secondary schools. Education and Information Technologies, 14(4), 345-363.

Johansone, I. (2016). Survey operations procedures in TIMSS 2015. In Martin, M. O., Mullis, I. V. S, \& Hooper, M. (Ed.), Methods and procedures in TIMSS 2015 (pp. 6.1 6.22). Chestnut Hill: TIMSS \& PIRLS International Study Center, Lynch School of Education, Boston College and International Association for the Evaluation of Educational Achievement (IEA). $\quad$ Retrieved from https://timssandpirls.bc.edu/publications/timss/2015methods/T15_MP_Chap6_Survey_Operations.pdf

Kruger, G. M. (2018). The relationship between investment in ICT and mathematics achievement. (Unpublished doctoral dissertation). University of Pretoria, Pretoria, South Africa.

Kubiatko, M., \& Vlckova, K. (2010). The relationship between ICT use and science knowledge for Czech students: A secondary analysis of PISA 2006. International Journal of Science and Mathematics Education, 8(3), 523-543.

Kul, Ü., Çelik, S., \& Aksu, Z. (2018). The impact of educational material use on mathematics achievement: A meta-analysis. International Journal of Instruction, 11(4), 303-324. 
LaRoche, S., \& Foy, P. (2016). Sample implementation in TIMSS 2015. In Martin, M. O., Mullis, I. V. S, \& Hooper, M. (Ed.), Methods and procedures in TIMSS 2015 (pp. 5.1 - 5.175). Chestnut Hill: TIMSS \& PIRLS International Study Center, Lynch School of Education, Boston College and International Association for the Evaluation of $\begin{array}{llll}\text { Educational Achievement } & \text { (IEA). } & \text { Retrieved }\end{array}$ https://timssandpirls.bc.edu/publications/timss/2015-methods/chapter-5.html

LaRoche, S., Joncas, M., \& Foy, P. (2016). Sample design in TIMSS 2015. In Martin, M. O., Mullis, I. V. S, \& Hooper, M. (Ed.), Methods and procedures in TIMSS 2015 (pp. 3.1 - 3.37). Chestnut Hill: TIMSS \& PIRLS International Study Center, Lynch School of Education, Boston College and International Association for the Evaluation of Educational Achievement (IEA). Retrieved from https://timssandpirls.bc.edu/publications/timss/2015-methods/chapter-3.html

Law, N., Pelgrum, W. J., \& Plomp, J. (2008). Pedagogy and ICT use in schools around the world: Findings from the SITES 2006 study (Vol 23). Hong Kong: CERC, University of Hong Kong and Springer Science. Retrieved from https://research.utwente.nl/en/publications/pedagogy-and-ict-use-in-schools-around-theworld-findings-from-th

Leedy, P. D., \& Omrod, J. E. (2010). Practical Research: Planning and design. Pearson.

Luu, K., \& Freeman, J. G. (2011). An analysis of the relationship between information and communication technology (ICT) and scientific literacy in Canada and Australia. Computers and Education, 56(4), 1072-1082. doi: 10.1016/j.compedu.2010.11.008

Martin, M., \& Mullis, I. V. S. (2012). Methods and procedures: TIMSS and PIRLS Stratified Two-Stage Cluster Sample Design. Boston: Chestnut Hill, MA: TIMSS \& PIRLS International Study Center. Retrieved from https://timssandpirls.bc.edu/methods/pdf/2Stage_Sample_Design.pdf

Mofokeng, P. L. S., \& Mji, A. (2010). Teaching mathematics and science using computers: How prepared are South African teachers to do this? Procedia - Social and Behavioural Sciences, 2(2), 1610-1614.

Mullis, I. V., Drucker, K. T., Preuschoff, C., Arora, A., \& Stanco, G. M. (2012). Assessment framework and instrumental development. Retrieved from https://timssandpirls.bc.edu/methods/pdf/TP_Instrument_Devel.pdf

Mullis, I. V., Martin, M. O., Foy, P., \& Hooper, M. (2016). TIMSS 2015 international results in mathematics. Retrieved from PIRLS International Study Center at Boston College. Retrieved from http://timssandpirls.bc.edu/timss2015/international-results/

Ndlovu, N. S., \& Lawrence, D. (2012). The quality of ICT use in South African classrooms. In Conference Paper presented at "Towards Carnegie III" Strategies to Overcome Poverty and Inequality. University of Cape Town, 1-27. Retrieved from http://www.mandelainitiative.org.za/images/docs/2012/papers/197_Ndlovu_The\%20qua lity\%20of\%20ICT\%20use\%20in\%20South\%20African\%20classrooms.pdf 
Nilsen, T., Gustafsson, J. E., \& Blömeke, S. (2016). Conceptual framework and methodology of this report. In T. Nilsen, J-E. Gustafsson (Ed.), Teacher quality, instructional quality and student outcomes (pp. 1-19). Cham: Springer.

Petko, D., Cantieni, A., \& Prasse, D. (2017). Perceived quality of educational technology matters: A secondary analysis of students' ICT use, ICT-related attitudes and PISA 2012 test scores. Journal of Educational Computing Research, 54(8), 1070-1091. doi:10.1177/0735633116649373

Ponzo, M. (2011). Does the way in which students use computers affect their school performance? Journal of Economic and Social Research, 13(2), 1-27.

Reddy, V., Isdale, K., Juan, A., Visser, M., Winnaar, L., \& Arends, F. (2017). Highlights of mathematics achievement amongst Grade 5 South African learners. Human Sciences Research Council. Retrieved from https://www.che.ac.za/sites/default/files/TIMSS\%202015\%20Grade\%205\%20Highlight s\%20document.pdf

Saal, P. E. (2017). Integrating computers into mathematics education in South African schools. (Masters' dissertation, University of Pretoria, Pretoria, South Africa). Retrieved from

https://repository.up.ac.za/bitstream/handle/2263/62904/Saal_Integrating_2017.pdf?seq uence $=1$

Semerci, A. (2018). Students' views on the use of tablet computers in education. World Journal on Educational Technology: Current Issues, 10(2), 104-114.

Skryabin, M., Zhang, J., Liu, L., \& Zhang, D. (2015). How the ICT development level and usage influence student achievement in reading, mathematics, and science? Computers \& Education, 85, 49-58.

Spiezia, V. (2010). Does computer use increase educational achievements? Studentlevel evidence from NSA. OECD Journal Economic Studies, 2010(1), 127-148.

Stols, G., Ferreira, R., Pelser, A., Olivier, W. A., Van der Merwe, A., De Villiers, C., \& Venter, S. (2015). Perceptions and needs of South African Mathematics teachers concerning their use of technology for instruction. South African Journal of Education, 35(4), 1-13.

Wittwer, J., \& Senkbeil, M. (2008). Is students' computer use at home related to their mathematical performance at school? Computers \& Education, 50(4), 1558-1571.

Zhang, D, \& Liu, L. (2016). How does ICT use influence students' achievements in Math and Science over Time? Evidence from PISA 2000 to 2012. EURASIA Journal of Mathematics, Science \& Technology Education, 12(9), 2431-2449. 